\title{
ANTON THOR HELLE TOIMETAJAKÄEKIRI: KUIDAS THOR HELLE VANA TESTAMENDI VERBIMORFOLOOGIAT REDIGEERIS
}

\author{
ANNIKA KILGI
}

Annotatsioon. Esimese eestikeelse täispiibli vana testamendi mustandit pani kirja kümmekond inimest, toimetamismärkmed pärinevad aga enamjaolt Anton Thor Helle sulest. Artiklis vaadeldakse neljateistkümne kirjutaja tekste vana testamendi kanooniliste raamatute osast. Täpsema analüüsi objektiks on kohad, kus toimetaja muutis verbigrammatikat.

Ilmnes, et Anton Thor Helle korrigeeris öeldiste ning määrusena tarvitatud infiniitvormide grammatikat sageli, umbes kolmandikul juhtudel, kuid enamasti oli tegu sõnastuse lihvimisega või kirjakoha sisulise ümbermõtestamisega ja mitte teistsuguse arusaamaga morfoloogiasüsteemist. Muudatusi, mis peegeldasid algse kirjutaja ja toimetaja erinevat verbigrammatikat, tegi Thor Helle silmatorkavalt palju üksnes Joachim Nicolaus Wilckeni, Heinrich Christoph Wrede ning Ruti raamatu tundmatu kirjutaja teksti redigeerides. Üldiselt tundub aga, et tõlkijad tegutsesid väga hoolikalt ja üksmeelselt ning toimetajal ei tulnud kuigivõrd põhimõttelisi parandusi teha.

Näiteks esines vaid paar üksikut erinevust kindlaks kujunenud infinitiivirektsioonist ning needki toimetas Thor Helle välja. Saama-tuleviku puhul nii suurt üksmeelt polnud, seda kasutas tervelt seitse kirjutajat neljateistkümnest ja Thor Helle eemaldas selle. Tema toimetajakäekirja kõige iseloomulikumaks jooneks võib pidada võtma-tarindit, mida ta rohkesti lisas.

Võtmesõnad: eesti kirjakeele ajalugu, piiblitõlge, morfosüntaks, toimetamine

1 Artikli valmimist on toetanud ETFi grant 7896. Suur tänu retsensentidele väga heade märkuste eest ning Kristiina Rossile ja Kai Tafenaule vana testamendi mustandkäsikirja paljunduste eest. 


\section{Sissejuhatuseks}

Eesti kirjakeele ajaloo uurijad on erakordselt õnnelikus olukorras, kuna praeguseni on säilinud siinse esmapiibli mitu toimetamisfaasi ning on võimalik üsna täpselt näha, kuidas lõpuks trükki jõudnud teksti keel tasapisi vormus. Uue testamendi umbes sajandipikkusele teekonnale täispiiblini mahtus kümmekond suuremate või väiksemate erinevustega redaktsiooni, sh kirikukäsiraamatutes leidunud evangeeliumi- ja epistlikatkendid, Heinrich Göseken vanema tõlge, Pilistvere piiblikonverentsil toimetatud käsikirja lõplik kuju, Müncheni käsikiri, 1715. aastal avaldatud raamat ja 1729. aasta põhjalikult toimetatud teine trükk. Vana testamendi tõlketöö jäi küll märksa lühemasse ajavahemikku, kahte kümnendisse, kuid sedagi käsikirja toimetati hoolikalt ning alg- ja lõppteksti vahele jäävad mustandkäsikiri, hilisem eraldi lehtedel paiknev parandusloetelu ja puhtandkäsikiri. Tänu nende redigeerimisetappide olemasolule on võimalik jälgida, mille poolest tõlkijate seisukohad erinesid ja kuidas jõuti lõpliku tekstini.

Nii ongi teada, et XVII sajandi lõpul uue testamendi põhjaeesti keelde tõlkimist saatnud erimeelsustes jäid peale Johann Hornungi, Adrian Virginiuse jt uuendusmeelsete ideed. Senisele Stahli-pärasele traditsioonile vastandudes loobuti näiteks saama-tulevikust ning põhiverbi muutmisest eitavas kõnes (Reila 2007: 559-560).

Järgmine seltskond, kelle tegevus mõjutas tugevalt kogu tollast eesti kirjakeelt, tekkis pärast Põhjasõda. Siis võttis hulk mehi (sh Heinrich Gutsleff, Eberhard Gutsleff noorem, Anton Thor Helle, Heinrich Christoph Wrede, Hermann Johann Heitzig) oma südameasjaks heakeelsete kirikuraamatute väljaandmise (Põldmäe 1939: 46, 51). See peamiselt pietistlikest pastoritest koosnev meeskond toimetas põhjalikult kirikukäsiraamatut ja uut testamenti, andis välja muid vaimulikke raamatuid ning senistest märksa põhjalikuma eesti keele käsiraamatu. Rudolf Põldmäe (1939: 58) sõnutsi tegutses Eestis toona märkimisväärselt palju kirjamehi, kes olid võimelised ja valmis võtma endale suuri ülesandeid ning sellest kirikuraamatuid väljaandvast seltskonnast tõusis üha enam esile Anton Thor Helle oma erakordse keeleandega. Nende kõige suurem ja kesksem töö oli täispiibli väljaandmine, mistarvis oli vaja peale uue testamendi redigeerimise tõlkida vana testament. Just viimase säilinud käsikirjad ${ }^{2}$

2 Siinse artikli jaoks kasutasin paberkoopiaid Eesti Ajalooarhiivis olevast vana testamendi mustandkäsikirjast (EAA, f 1187, n 2, s 5324 ja 5325). 
annavadki hea sissevaate eesti kirjakeele kujundamisse vahetult enne täispiiblit, 1720.-30. aastatel.

Teada saamaks, kuivõrd tollaste kirjakeele kujundajate seisukohad üksteisest erinesid ja milliste põhimõtete järgi varieeruvust ühtlustati, võrdlesin vana testamendi mustandis olevate eri käekirjadega kirjutatud osade verbigrammatikat. Nõnda peaks saama selgemaks, kuidas suhestusid eri kirjutajate arusaamad parimast eesti (raamatu)keelest. Konkreetsema analüüsi objektiks olid need verbivormid ja -tarindid, millega toimetamise käigus tegeldi. Valisin neljateistkümnest vana testamendi kanoonilises osas eristatud käekirjast ühepikkused, 56-salmilised katkendid ${ }^{3}$ ning analüüsisin kõiki verbijuhtumeid, mida Thor Helle toimetanud oli. Arvesse ei läinud puhtleksikaalsed muudatused, nt asendus kutsus $>$ hüüdis. Jälgisin, kui palju muutis toimetaja verbigrammatikat, nt pani algse verbivormi ep olnud asemele ei olnud, saab asemele saaks või ei taha võtta asemele ei võta. Omavahel võrdlesin algse kirjutaja lõplikku tahet toimetaja lõpliku tahtega, s.t mustandkäsikirja algse kirjutaja viimast sõnastust trükipiibliga. ${ }^{4}$

3 Eberhard Gutsleffilt Ps 52:1-56:6, Heinrich Gutsleffilt 4Ms 31:5-31:32 ja 32:1-32:29, Johann Christoph Gutsleffilt Kg 1:1-3:12, Johann Laurentius Hesselt 1Ms 1:1-2:25, Michael Levanuselt 1Sm 1:1-2:28, Georg Sablerilt Esr 4:1-6:2, Joachim Salemannilt Ho 1:1-4:17, Anton Thor Hellelt 4Ms 5:5-7:2, Joachim Nicolaus Wilckenilt Ha 1:1-3:19, Heinrich Christoph Wredelt Am 1:1-4:10 ning neljalt tundmatult kirjutajalt 2Sm 1:1-2:29, Est 1:1-3:11, Jr 1:1-3:12 ja Rt 1:1-3:11. Christoph Erdmann Biecki käega kirjutatud osades on parandusi niivõrd vähe, et nende näol pole tõenäoliselt tegu mitte algse mustandi, vaid mustandi ümberkirjutusega, seetõttu ei ole temalt katkendit analüüsitud.

Katkendi pikkuseks on valitud 56 salmi, kuna just nii palju salme oli kirja pannud kõige vähem kirjutanud J. N. Wilcken. Talt on seetõttu võetud analüüsiks kogu tema käega kirjutatud tekst, terve Habakuki raamat, ja ülejäänutelt sama pikk osa nende kirjutatust.

${ }^{4}$ Ehkki mustandkäsikirja lõplik kuju ei erine tavaliselt kuigivõrd trükipiiblist, on siiski palju parandusi lisandunud ka pärastpoole. Näiteks Ps 53:3 pani Eberhard Gutsleff noorem kõigepealt mustandisse kirja kujul Jummal on taewast tunnistanud innimesse lapsed, et ta piddi näggema, kas üks moistlik olleks, kes Jummalat otsiks öiete. Thor Helle toimetas selle mustandkäsikirjas Jummal watab taewast innimesse laste peäle, et ta saaks nähha, kas kegi moistlik olleks, kes öiete otsiks Jummalat ja trükipiiblisse jõudis Jummal wadab taewast innimesse laste peäle, et ta saaks nähha, kas kegi moistlik olleks, kes Jummalat nouaks. Seega muutis toimetaja mustandkäsikirjas neljast öeldisest kahe grammatikat (on tunnistanud > 
Paratamatult on taoline valim üsna väike ja juhuslik ega luba jõuda nii paljudele ja kindlatele järeldustele kui mahukama teksti analüüs. Seetõttu tuleb arvestada, et vaadeldud materjali põhjal kirjutajale omistatud omadused ei pruugi kõigi tema käega kirjutatud ridade kohta kehtida. Ometigi tundus juba ka lühikesi katkendeid vaadeldes ilmnevat nii kirjutajate erijooni kui ka ühtlustamispõhimõtteid.

Issand annab räkida, hea sannumette tojaid on suur hulk.

(Ps 68:12)

\section{Kirjutajad}

Vana testamenti aitas 1720.-30. aastatel trükki toimetada üsna suur seltskond: kanooniliste raamatute mustandkäsikirjas on Kristiina Ross (2002) ja Kai Tafenau (2009) eristanud viisteist käekirja, ${ }^{5}$ apokrüüfides lisandub

watab, piddi näggema > saaks nähha) ning hilisemal redigeerimisel neist üksnes ühe öeldise tüve (watab > wadab).

5 Nende käekirjadega on kirjutatud järgmised tekstiosad (Ross 2002, Tafenau 2009).

\begin{tabular}{|c|c|}
\hline A. Thor Helle & $\begin{array}{l}4 \text { Ms } 1: 1-31: 3 \text { (poole pealt); } 5 \text { Ms } 1-19,32: 10-34: 12 ; 1 \mathrm{Kn} \\
1-11 ; \text { Ii } 21: 1-31: 40 ; \text { Ps } 2-33,106-107,117-118,120-128\end{array}$ \\
\hline H. Gutsleff & $\begin{array}{l}\text { 4Ms 31:3 (poole pealt) - 36:13; 5Ms 20-31; Jos; } 1 \mathrm{Kn} 12-22 \text {; } \\
\text { 2Kn; Ii 1-20; Ps 36-50, 64; Tn; Sf; Ml }\end{array}$ \\
\hline J. C. Gutsleff & Õp; Kg; Ül; Ps 70-105 \\
\hline H. C. Wrede & $\begin{array}{l}\text { Am; Ob; Jn 1:1-3:4, Ps 108-117; 2Kn 20:12-21, 21:9-26; } \\
\text { Ii 34:28-36:16 }\end{array}$ \\
\hline J. L. Hesse & $\begin{array}{l}\text { 1Ms, 2Ms, 3Ms (2Ms-i ja 3Ms-i algusleheküljed Thor } \\
\text { Hellelt) }\end{array}$ \\
\hline tundmatu & $\mathrm{Jr} ; \mathrm{Nl} ;$ Ps $129-150$ \\
\hline J. Salemann & Hs; Ho; Jl; Ps 61-63 \\
\hline M. Levanus & Jn 2:7 (poole pealt) $-4: 11 ; \mathrm{Mi} ; \mathrm{Na}$ \\
\hline G. Sabler & Esr; $\mathrm{Ne}$ \\
\hline tundmatu & 1Sm; Est \\
\hline tundmatu & $2 \mathrm{Sm}$ \\
\hline J. N. Wilcken & $\mathrm{Ha}$ \\
\hline tundmatu & $\mathrm{Rt}$ \\
\hline E. Gutsleff noorem & Ps $34,35,50-60$ \\
\hline C. E. Bieck & $\begin{array}{l}2 \mathrm{Kn} 4: 1-33,6: 4-33,19: 20-20: 11,25: 11-30 ; \text { Tn } 3: 21-4: 13 \text {, } \\
5: 18-7: 20,9: 25-11: 38 ; \operatorname{Km} 18: 8-12,18: 18-19\end{array}$ \\
\hline
\end{tabular}

Kõiki raamatukatkendeid, kus käekiri järsku muutub, pole siinses loendis esitatud. 
veel seitse (Tafenau 2009: 703). Apokrüüfides lisanduvate käekirjade autorid on teadmata, kanooniliste raamatute käekirjade omanikest on seni tuvastamata neli. Ülejäänud on Rossi ja Tafenau andmetel Jüri pastor Anton Thor Helle, Kullamaa pastor Heinrich Gutsleff, Suure-Jaani pastor Johann Christoph Gutsleff, Harju-Jaani ja Jõelähtme pastor Heinrich Christoph Wrede, Keila koduõpetaja Johann Laurentius Hesse, Mihkli pastor Joachim Salemann, Kirbla ja Lihula pastor Michael Levanus, Haljala pastor Georg Sabler, Hageri pastor Joachim Nicolaus Wilcken, Tallinna Pühavaimu pastor Eberhard Gutsleff noorem ja Tallinna gümnaasiumi õpetaja Christoph Erdmann Bieck. Seega ei olnud piibli väljaandmisse kaasatud inimesi mitte ainult Tallinnast ja selle lähiümbrusest, vaid kaugematestki põhjaeesti murdeala kohtadest (vt joonist).

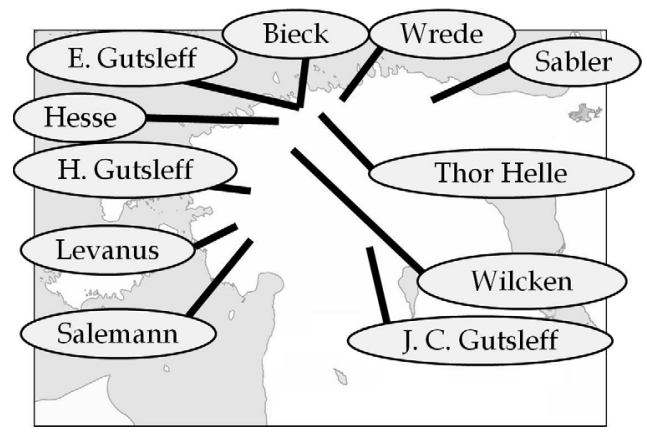

Joonis. Vana testamendi tuvastatud kirjutajate töökohad

Kaugeltki alati pole selge, kas teksti kirjapanijad olid muutusteta ümberkirjutajad, revideerivad ümberkirjutajad või tõlkijad. ${ }^{6}$ Seda, et osa mustandkäsikirjast pole ilmselt mitte algne tõlge, vaid ümberkirjutus, paneb oletama asjaolu, et selles on vähe parandusi ning käekiri muutub mõnikord isegi lause keskel (Ross 2002: 77-78). Need suhteliselt puhtad kohad on 4Ms-i 1õpp (alates 31:3-st), suurem osa 5Ms-ist, Js, Km, 1Kn, 2Kn, Ii, Js, Tn, Sf, Hg ja Ml. Kõige rohkem on seal Thor Helle ja H. Gutsleffi käekirja, vähem Wredet ja Biecki. (Tafenau 2009: 697)

${ }^{6}$ Mõtteainet pakub näiteks Otto Wilhelm Masingu kiri Johann Heinrich Rosenplänterile 3. jaanuaril 1819, kus Masing ühe uue testamendi kirjakoha sõnastust kommenteerides ütles: „Meie kõik kokku ei tee viiendikkugi sellest, mis nood 11 ära tegid." Pole teada, mille põhjal Masing oletas, et piibli eesti keelde tõlkijaid oli just nimelt 11. (Anvelt jt 1996: 22-25) 
Kõige tõenäolisemalt võib teksti pidada kirjutaja tõlgituks siis, kui kirjutaja oli järjest kirja pannud pika teksti, millesse tehti hiljem ka palju parandusi. Sel juhul tundub mõistlik arvata, et tegemist on algmustandi, mitte ümberkirjutusega, ning loogilisim kandidaat oma tõlget kirja panema paistab olevat tõlkija ise. Mõnel juhul saab kirjutajate panust eelnevasse tõlketöösse hinnata kaudsete andmete põhjal, nagu seda on Jüri kirikuraamatus olev Thor Helle märkus Esimese Moosese raamatu tõlkimise kohta koos kellegi hea sõbraga (Ross 2002: 75) ning Otepää pastori teade, et see hea sõber, kes Thor Hellel grammatikatki koostada aitas, oli Hesse (Tafenau 2009: 704). Kuna mustandkäsikirjas ongi tekst kirja pandud selle hea sõbra käega (Tafenau 2009: 704), olnuks ilma Thor Helle teateta ilmselt palju raskem Hesse osalust tuvastada.

Ka toimetamismärkmete kohta on Kai Tafenau (2009: 699) oletanud, et ehkki need pani enamjaolt kirja Thor Helle, võis ta olla neid enne H. Gutsleffiga arutanud. Viimaste tihe koostöö kajastub veel näiteks nende käekirjade järgnemises üksteisele $4 \mathrm{Ms}-\mathrm{i}, 5 \mathrm{Ms}-\mathrm{i}, 1 \mathrm{Kn}-\mathrm{i}$ ja Ps-i tõlgetes (Ross 2002: 78).

Ehkki kirjutajate täpset panust tõlkimisse või toimetamisse on tagantjärele üsna raske välja selgitada, on igal juhul selge, et Anton Thor Helle pilgu alt käis läbi kogu vana testament ja seda mitu korda: tema käsi ei ole kirjutanud suuremat osa märkmetest mitte ainult otse mustandkäsikirja, vaid ka hilisemasse eraldi lehtedel paiknevasse parandusloetellu (Tafenau 2009: 699). Thor Helle tehtud parandused näitavad igal juhul tema keelelisi põhimõtteid, ükskõik, kas ta neid enne kellegagi arutas või mitte. Samamoodi võib oletada, et ka toimetamiseelse teksti kirjutajad ei pannud kirja midagi enda keeletaju riivavat.

Eri käega kirja pandud tekstiosade keelekasutus tundub olevat verbimorfoloogia poolest üsna ühtlane. Üldpildist eristuvad vaid mõne kirjutaja üksikud jooned.

Individuaalsed paistavad olevat näiteks lahknevused üldiselt välja kujunenud infinitiivirektsioonist. Nii esines ainult tundmatul Estri raamatu tõlkijal ,pidama + da-tegevusnimi” (2 korda), Wredel ,tahtma + ma-tegevusnimi” (16 korda, Thor Hellel endal siiski ka 1 kord), Wredel „võima + ma-tegevusnimi” (1), J. C. Gutsleffil ,panema + da-tegevusnimi” (2).

Teiste seas paistis silma Ruti raamatu tundmatu kirjutaja, kes lisas eitusvormi moodustamiseks jaatusvormile mitte ja käskiva kõneviisi puhul ära ka mitmuses. Nii kirjutas ta et sind sest Mehhest mitte enne tähhel 
pannakse > Thor Helle et sinna ei sa selle mehhele teäda (Rt 3:3); et ma küll mitte ollen kui üks so ommast ümmerdajast > Thor Helle ehk ma kül mitte ei olle kui üks so ümmardajaist (Rt 2:13) ja ärra hü̈üke mind Noomiks > Thor Helle ärge hü̈̈dke mind Noomiks (Rt 1:20).

Eitust väljendas ülejäänuist erinevalt ka Wrede, kes lisas verbile pöördetunnuse. Wrede toimis nii kuus korda ja Thor Helle toimetas selle alati välja, nt Wrede ei tahhan ma sedda mitte taggasi wötma $>$ Thor Helle ei tahha ma sedda sanna mitte taggasi wötta (Am 1:11).

Just Wrede ja Wilckeni tekste parandaski Thor Helle kõige rohkem. Wilckeni kirjutatud Habakuki raamatu 244 öeldisest jättis Thor Helle grammatika puutumata vaid 98-1 ja Wrede tõlgitud Aamose raamatu alguse 212 öeldisest 89-1. Skaala teises otsas on Hesse käega kirjutatud Esimene Moosese raamat, mille Thor Helle ja Hesse koos tõlkinud olid: sealsest 195 öeldisest jättis toimetaja grammatika muutmata tervelt 178 puhul. Ülejäänud käekirjadega katkendid jäid parandatud verbivormide osakaalu poolest nende vahele.

Se on rööm kuulda, kui kegi hästi kostab, ja se sanna, mis öigel a-al rägitakse, on wägga hä.

(Õp 15:23)

\section{Anton Thor Helle toimetamistöö}

Thor Helle muutis verbigrammatikat üsna palju - tervelt kolmandikul juhtudel: 3142 öeldisest ja määrusena kasutatud infiniitvormist 1120-1 ehk $36 \%-1$. Rohkete paranduste seas leidub aga vähe selliseid, mida toimetaja tegi nii sageli, et neid võib pidada tema jaoks põhimõtteliseks. Enamasti esines mingi parandus vaid üks-kaks korda ühe-kahe kirjutaja tekstis.

Näiteks toimetas Thor Helle tarindit ,andma $+d a$-tegevusnimi” küll tervelt 12 korda, kuid kõik need parandused erinesid üksteisest: toimetaja asendas andma-tarindiga Jeremija raamatu kirjutajal laskma-tarindi (1), J. C. Gutsleffil panema-tarindi (4), Levanusel saama-tarindi (1) ning Wredel ja Wilckenil lihtverbi (kummalgi 1). Mõnikord ta hoopis eemaldas andma-konstruktsiooni, siis tuli selle asemele Salemannil pidama-tarind (1) ja Wredel lihtverb (2). Võiks ju oletada, et kõnealune konstruktsioon meeldis Thor Hellele, kuna ta toimetas seda märksa sagedamini sisse (9) kui välja (3), aga nii väheste ja erinevate esinemiskordade põhjal ei ole võimalik väita, et tal oleks olnud väljakujunenud seisukoht, milliste 
teiste väljendusviiside asemel ja millistes kontekstides andma-tarindit kasutada.

Rohkem võib Anton Thor Helle eelistusi välja lugeda sellistest muudatustest, mida ta tegi sageli, s.t toimetades vähemalt kolme kirjutaja teksti. ${ }^{7}$ Need kõige levinumad morfoloogiamuudatused näitavad, millised teemad olid toimetaja jaoks kõige olulisemad. Põhimõttelisuse alusel võib need jagada kolme liiki:

1) muudatused, mida Thor Helle tegi alati ühtpidi;

2) muudatused, mida Thor Helle tegi enamasti ühtpidi;

3) muudatused, mida Thor Helle tegi enam-vähem võrdselt mõlematpidi.

3.1. Alati ühtpidi tehtud muudatused. Thor Hellel oli kindel arvamus kahe tarindi kohta: konstruktsiooni ,saama + ma-tegevusnimi” toimetas ta alati välja, konstruktsiooni ,võtma $+d a$-tegevusnimi” ei eemaldanud ta seevastu kordagi, küll aga lisas juurde, kõige sagedamini saama-tuleviku ning pidama- ja tahtma-ühendite asemele.

Saama-tulevikust oli eesti piiblitõlke traditsioonis loobutud juba XVII sajandi lõpus ning seda kasutaski tulevikulisuse väljendamiseks rohkesti ainult kolm tõlkijat: Wilcken (25 korda), Wrede (10) ja Ruti raamatu

${ }^{7}$ Nende muudatuste loend on artikli lisas. Loend on jagatud kaheks: a) morfeemikujude muudatused, b) morfosüntaktilised muudatused, kusjuures käesolevas artiklis tuleb edaspidi juttu ainult viimastest.

Esimeste kohta olgu aga märgitud, et grammatiliste või leksikaalsete morfeemide kuju muutis Thor Helle alati ühtpidi. Mineviku kesksõna tunnuse nud asemele toimetas Thor Helle $n d$ (14 korda 6 käekirjas ehk lühidalt 14/6), nt E. Gutsleff Temma on minno hinge rahho sees lunnastanud $>$ Thor Helle Ta on mo hinge rahho sees lunnastand (Ps 55:19). Ehkki Thor Helle ei teinud ainsatki vastupidist muudatust, ei rakendanud ta ka muudatust $n u d>n d$ kaugeltki igal võimalusel ja täispiibli keeles on valdav nud.

Tüve muutmisega oli teisiti. Seal valis Thor Helle alati välja eelistatud tüvekuju: andnud $>$ annud (9/6), tundnud $>$ tunnud (4/4), räägis > rä̈̈kis (11/6) ja analoogsed parandused sama verbi muudes vormides (10/5), ütelda $>$ öölda (4/4). Sama põhimõttelisi muudatusi oli oletatavasti veel küllaga, kuigi need ei juhtunud olema käesoleva uurimuse aluseks olevas valimis sagedased, nt pantakse $>$ pannakse $(2 / 2)$, vaatke, vaatake $>$ vaadage $(2 / 2)$, ütlis $>$ ütles $(2 / 1)$, keelasid $>$ keelsid $(1 / 1)$, käskinud $>$ käsknud (1/1), pääsenud $>$ pääsnud (1/1), tahtvad $>$ tahavad (1/1), tegevad $>$ teevad (1/1). Siiski on teada, et täispiibli keeles esineb sama vorm eri kujul, nt teevad ja tegevad (Saareste 1940). 
tundmatu kirjutaja (8). Üksikjuhte tuli aga ette teistelgi: Sableril (2), E. Gutsleffil (1), J. C. Gutsleffil (1) ja Estri raamatu tundmatul kirjutajal (1). Selle artikli valimis olnud tekstidest toimetas Thor Helle selle keelendi alati välja, nt Wilcken Se Öige agga saab omma Ussu lebbi ellama > Thor Helle kes öige on ommas uskus, se peab ellama (Ha 2:4). Täispiiblisse on siiski harvad saama-futuurumi juhud jäänud (Mägiste 1936: 37).

Vastupidi saama-tuleviku kirjakeelest tõrjumisele, mis oli alanud juba XVII sajandi lõpul, oli võtma-tarindi soosimine eriti iseloomulik just täispiibliaegsetele teostele, kus seda esines märksa rohkem kui varasemates eestikeelsetes tekstides (Kilgi 2010: 177). Vana testamendi käsikirja põhjal tundub, et selle tarindi suurenenud populaarsuse põhjuseks on Thor Helle isiklik sümpaatia, kuna just tema on oma toimetajakäega seda ohtrasti lisanud ja mitte kordagi eemaldanud. Ta tõi seda juurde 30 korda 6 kirjutaja tekstides, nt Salemann Wimaks peab ennast Israeli rahwas pöörma, ja otsima sedda Issandat nende Jummalat > Thor Helle Pärrast wötwad Israeli lapsed pöörda ja otsida Jehowat omma Jummalat (Ho 3:5).

Peale nende tarindite oli Thor Hellel selge eelistus ka infinitiivirektsiooni suhtes. Pille Penjam on oma doktoritöös (2008) näidanud, et paljudes XVII sajandi kirjakeele tarindites varieerus $m a$ - ja $d a$-infinitiivi kasutus, nt Heinrich Stahli tekstis seisis ühes kohas võib sündima ja teises võid saada, Christoph Blumel ühes kohas peab sündima ja teises peab olla. Vana testamendi mustandis oli taoline $m a$ - ja $d a$-infinitiivi varieeruvus peaaegu kadunud. Neil üksikuil juhtudel, mis kindlaks kujunenud normist veel erinesid, toimetas Thor Helle alati sisse selle infinitiivi, mida ka tänapäeva kirjakeeles selles tarindis kasutatakse, nt Wrede tahhan katki murdma $>$ Thor Helle tahhan katkimurda (Am 1:5). Infinitiivirektsioon lahknes nüüdiskeelsest algseski variandis väga harva (vt täielikku loendit 2. peatükis).

3.2. Enamasti ühtpidi tehtud muudatused. Järgmisse rühma võib paigutada muudatused, mida Thor Helle ei teinud küll alati ühtpidi, kuid siiski ühes suunas ülekaalukalt rohkem kui teises. Näiteks toimetas ta liitmineviku vormist abiverbi olema välja lausa 29 korda 13 käekirjas (29/13), sisse aga ainult 5 korda 5 käekirjas (5/5), vrd J. C. Gutsleff mis ial on olnud $>$ mis ial olnud (Kg 1:9) ja sest et nemmad täieste Issanda järrel käinud $>$ Thor Helle sest nemmad on täieste Jehowa järrel käinud (4Ms 32:12). 
Samamoodi eelistas ta eitusvormi eitussõna mitte pigem lisada (24/11) kui eemaldada (6/5), vrd Levanus Hanna nuttis ning ei sönud middagi $>$ Thor Helle Anna nuttis, ja ei sönud mitte (1Sm 1:7) ja E. Gutsleff Se jälle ütleb ommas süddames: polle ükski Jummal mitte $>$ Thor Helle Se, kes jölle, ütleb ommas süddames: Ei polle Jummalat (Ps 53:2).

\subsection{Enam-vähem võrdselt mõlematpidi tehtud muudatused. Ülejää-} nud sagedasi muudatusi tegi Thor Helle palju mõlematpidi, mis näitab, et tegemist oli küll toimetaja jaoks olulise teemaga, kuid ta ei eelistanud üht väljendusviisi teistele, vaid langetas otsuse konteksti põhjal.

Paljudel sellistel juhtudel on tegemist sisuliste parandustega, kui algne kirjutaja oli mõtestanud tõlgitavat kirjakohta toimetajast erinevalt. Näiteks Ho 2:10-s seisis Salemanni tekstis kõigepealt pidama-ühend, mis väljendas, et tegevus on tulevikuline ja/või tegijatele kohustuslik (nemmad peawad naeste jure minnema), Thor Helle aga asendas selle laskma-tarindiga, mis rõhutas hoopis seda, et tegijad kohustavad kedagi teist (nemmad lassewad horatööd tehha).

Mõlematpidi sageli tehtud muudatused seisnesid tihti ka peenes sõnastuse lihvimises, nt ainsuse sissetoimetamine Teise Saamueli raamatu tundmatu kirjutaja teksti: mustandkäsikirjas algselt olnud sõnastusest seäl ollid kolm Seruja poega, Joab ning Abisai ning Asahel sai täispiiblis seäl olli kolm Seruja poega, Joab ja Abisai ja Asael (2Sm 2:18).

Olenemata sellest, kas toimetaja pigem lihvis olemasolevat sõnastust või mõtestas tõlgitava koha sisuliselt ümber, võib öelda, et mõlematpidi sageli tehtud parandused ei anna märku sellest, et kirjutajad ja toimetaja oleksid eesti verbimorfoloogiat erinevalt tajunud, vaid et nad eelistasid konkreetse kirjakoha tõlkimisel eri keelendeid.

Nii toimetas Thor Helle kord sisse, kord välja des-vormi, pidama-, tahtma-, panema-, laskma-, võima- ja ,olema + mas” -tarindeid ning muutis verbivormis aega, kõneviisi, kõneliiki, tegumoodi või arvu. Selliste muudatuste taga on raske otsida mingit üldist põhimõtet, kuivõrd heebrea ja eesti verbisüsteem on väga erinevad. ${ }^{8}$

${ }^{8}$ Kristiina Ross on Ülemlaulu verbivorme analüüsides jõudnud järeldusele, et raamat on tõlgitud otse heebrea keelest saksa tõlgete abita, ehkki tekstis on sellest hoolimata palju saksapärast (Ross 1995: 188). Kuigi praeguse uurimisseisu põhjal võib eeldada, et täispiibli vana testament on tõlgitud heebrea keelest, ei ole teada, kas algkeelest lähtusid kõik tõlkijad. Mustandkäsikirja esimest sõnastust pole saksa 
Näiteks toimetas Thor Helle des-vormi sisse seitsmes käekirjas ja välja kaheksas käekirjas, vrd J. C. Gutsleff neid se läbbi waewades > Thor Helle et ta neid se läbbi piddi waewama $(\mathrm{Kg} 3: 10)$ ja tundmatu Kunninga Wraua Wasti ei tahtnud tulla > Thor Helle kunninga-emmand Wasti törkus tulles (Est 1:12).

Väga levinud oli ka verbivormis ühe morfoloogilise kategooria asendamine teisega, nt tegumoe vahetus, vrd Sabler ja nemmad leidsid ühhe waskse Wlaski sees ühhe Ramato > Thor Helle siis leiti ühhest laekast üks ramat (Esr 6:2) ning tundmatu ja se Naine jäeti ilma omma kahhest Pojast, ja omma Mehhest > Thor Helle ja se naene jäi jälle ommast kahhest poiast ja ommast mehhest (Rt 1:5).

Samuti redigeeris Thor Helle sageli mõlematpidi konstruktsioone, kõige enam pidama- ja tahtma-tarindit (esimest sisse 58/11 ja välja 32/12, teist sisse 29/6 ja välja 38/7). Tahtma-ühendi mõlematpidi toimetamist illustreerigu järgmised kaks näidet: Levanus ta tahhab omma pühhade jallad hoida > Thor Helle ta hoiab omma waggade jallad (1Sm 2:9) ja Wrede ei wötta taggasi > Thor Helle ei tahha mitte taggasi wötta (Am 1:3).

\section{Kokkuvõtteks}

Vana testamendi kanoonilist osa pani kirja viisteist isikut, toimetamismärkmed pärinevad aga enamjaolt Anton Thor Hellelt, kes muutis umbkaudu kolmandiku öeldiste grammatikat. Sealjuures on valdavalt tegu peene sõnastuse lihvimisega või kirjakoha sisulise ümbermõtestamisega, mis ei viita eesti keele grammatilise süsteemi erinevale tajumisele. Kõige rohkem põhimõttelisi parandusi tegi toimetaja Ruti raamatu kirjutaja ning Wrede ja Wilckeni tekstis, mujal oli neid vähe.

Tundub, et tõlkijad tegid oma tööd väga hoolikalt ning seetõttu polnud Thor Hellel põhimõttelisi parandusi eriti tarvis teha. Siiski leidus ka keelendeid, mida Thor Helle toimetas alati ühtpidi ning ühtlustas sellega tõlkijameeskonna keelekasutuse varieeruvust: ta tõrjus igalt poolt välja seitsmel kirjutajal esinenud saama-tuleviku ning kirjutas juurde rohkesti võtma-tarindeid. Infinitiivirektsiooni puhul oli ta samuti kindlameelne, kõrvaldades üksikuil kirjutajail esinenud lahknevused üldisest tavast.

tõlgetega võrreldud, kuid üks võimalus sealseid erinevusi põhjendada oleks oletus, et kõige rohkem redigeeritud tekstide tõlkijad lähtusid teistsugus(t)est teksti(de)st kui toimetaja. 
Niisiis on vana testamendi tõlge vähemasti verbimorfoloogia koha pealt kujunenud suhteliselt ühtses ja suuremate erimeelsusteta meeskonnatöös, kus on siiski selgelt tuntav Thor Helle toimetajakäekiri.

\section{Vana testamendi raamatute lühendid}

$\begin{array}{ll}1 \mathrm{Ms}=\text { Esimene Moosese raamat } & \mathrm{Kg}=\text { Koguja } \\ 2 \mathrm{Ms}=\text { Teine Moosese raamat } & \text { Ül }=\text { Ülemlaul } \\ 3 \mathrm{Ms}=\text { Kolmas Moosese raamat } & \mathrm{Js}=\text { Jesaja } \\ 4 \mathrm{Ms}=\text { Neljas Moosese raamat } & \mathrm{Jr}=\text { Jeremija } \\ 5 \mathrm{Ms}=\text { Viies Moosese raamat } & \mathrm{Nl}=\text { Nutulaulud } \\ \mathrm{Jos}=\text { Joosua raamat } & \mathrm{Hs}=\text { Hesekiel } \\ \mathrm{Km}=\text { Kohtumõistjate raamat } & \mathrm{Tn}=\text { Taaniel } \\ \mathrm{Rt}=\text { Rutt } & \mathrm{Ho}=\text { Hoosea } \\ 1 \mathrm{Sm}=\text { Esimene Saamueli raamat } & \mathrm{Jl}=\text { Joel } \\ 2 \mathrm{Sm}=\text { Teine Saamueli raamat } & \mathrm{Am}=\text { Aamos } \\ 1 \mathrm{Kn}=\text { Esimene kuningate raamat } & \mathrm{Ob}=\text { Obadja } \\ 2 \mathrm{Kn}=\text { Teine kuningate raamat } & \mathrm{Jn}=\text { Joona } \\ 1 \mathrm{Aj}=\text { Esimene ajaraamat } & \mathrm{Mi}=\text { Miika } \\ 2 \mathrm{Aj}=\text { Teine ajaraamat } & \mathrm{Na}=\text { Nahum } \\ \text { Esr }=\text { Esra } & \mathrm{Ha}=\text { Habakuk } \\ \mathrm{Ne}=\text { Nehemja } & \mathrm{Sf}=\text { Sefanja } \\ \text { Est }=\text { Ester } & \mathrm{Hg}=\text { Haggai } \\ \mathrm{Ii}=\text { Iiob } & \mathrm{Sk}=\text { Sakarja } \\ \mathrm{Ps}=\text { Psalmid } & \mathrm{Ml}=\text { Malaki } \\ \text { Ôp }=\text { Opetussõnad } & \end{array}$

\section{Kirjandus}

Anvelt jt 1996 = Leo Anvelt, Eva Aaver, Heli Laanekask, Abel Nagelmaa. Otto Wilhelm Masingu kirjad Johann Heinrich Rosenplänterile. Teine köide 1819-1820. Tartu: Eesti Kirjandusmuuseum.

Kilgi, Annika 2010. Tuleviku tulekust: tulevikulisuse väljendamisest meie esimestes piiblitõlgetes. - Keele rajad. Pühendusteos professor Helle Metslangi 60. sünnipäevaks. Paths of language. Festschrift for professor Helle Metslang on the occasion of her 60th birthday. (= Eesti ja soomeugri keeleteaduse ajakiri. Journal of Estonian and Finno-Ugric Linguistics 1-2.) Tartu: ESUKA-JEFUL, 163-185.

Mägiste, Julius 1936. Eesti saama-futuurumi algupärast ja tarvitamiskõlblikkusest. - Eesti Keel 3, 65-92. 
Penjam, Pille 2008. Eesti kirjakeele $d a$ - ja $m a$-infinitiiviga konstruktsioonid. Tartu: Tartu Ülikooli Kirjastus.

Põldmäe, Rudolf 1939. Anton Thor Helle: esimese eesti piibli tõlkija. - Vana Tallinn. IV köide. Toim. Paul Johansen, Rudolf Kenkmaa, Hugo Peets, Arnold Süvalep. Tallinn: Tallinna Ajaloo Selts, 35-74.

Reila, Heiki 2007. Müncheni käsikirjast ja selle seostest Johann Hornungi tõlkega: keelelisi tähelepanekuid. - Põhjaeestikeelsed Uue Testamendi tõlked 1680-1705: Luuka evangeelium. Apostlite teod. Koost. Kristiina Ross. Toim. Heiki Reila, Kristiina Ross, Kai Tafenau. Tallinn: Eesti Keele Sihtasutus, 556-563.

Ross, Kristiina 1995. Verbivormide tõlkest esimeses eestikeelses täispiiblis (Ülemlaulu põhjal). - Läänemere rahvaste kirjakeelte ajaloost. (= Tartu ülikooli eesti keele õppetooli toimetised 1.) Tartu: Tartu ülikooli kirjastus, $176-189$.

Ross, Kristiina 2002. Esialgseid täiendusi Vana Testamendi tõlkeloole. - Keel ja Kirjandus 2, 73-87.

Saareste, Andrus 1940. Piibli keel ja rahvakeel. - Piibli keelest: Kahesajaaastast eestikeelset piiblit mälestades. (=Akadeemilise Emakeele Seltsi toimetised XLIV.) Tartu 1940, 12-64.

Tafenau, Kai 2009. Veel täiendusi Vana Testamendi tõlkeloole. - Keel ja Kirjandus 8-9, 688-708. 


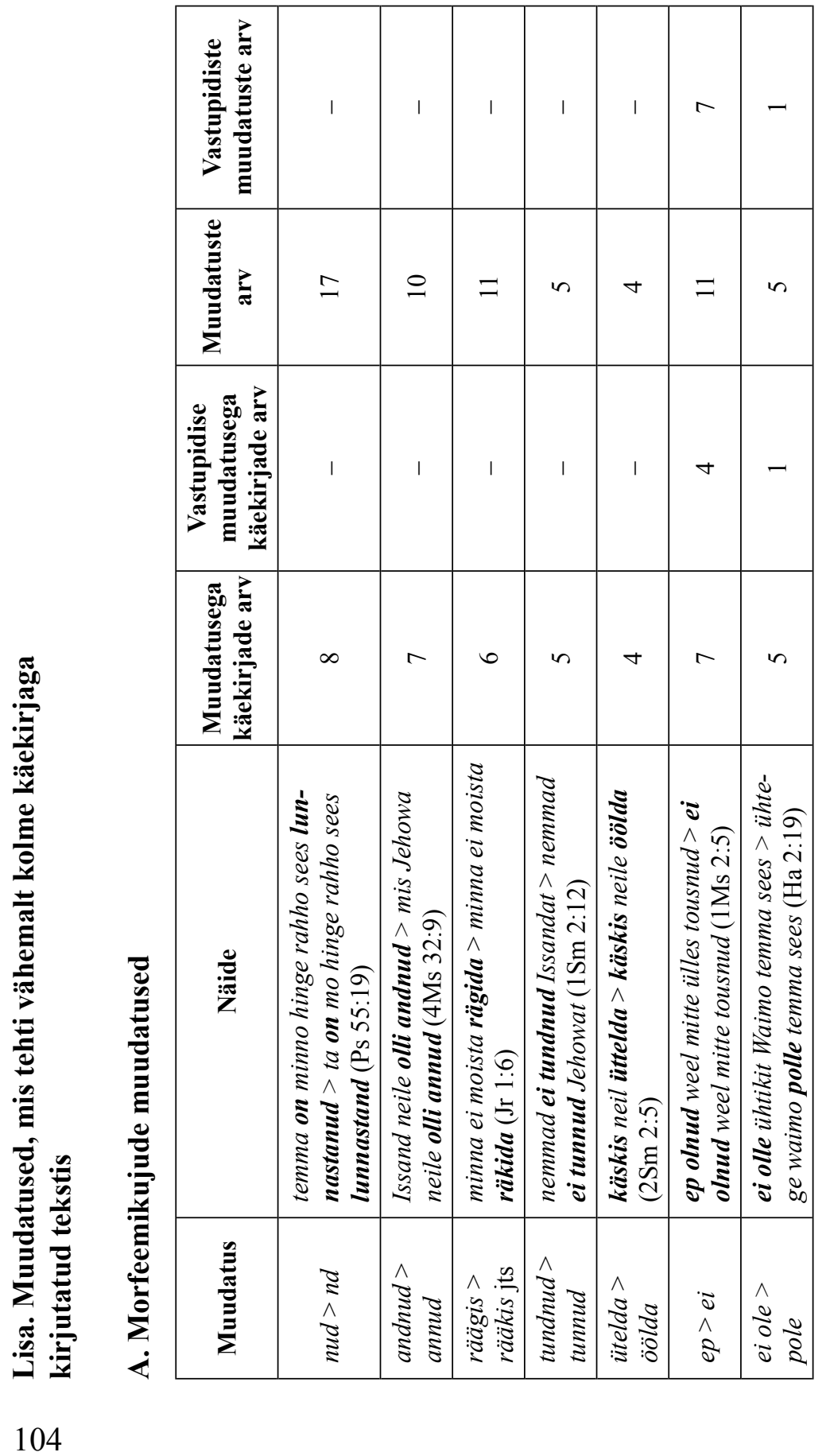




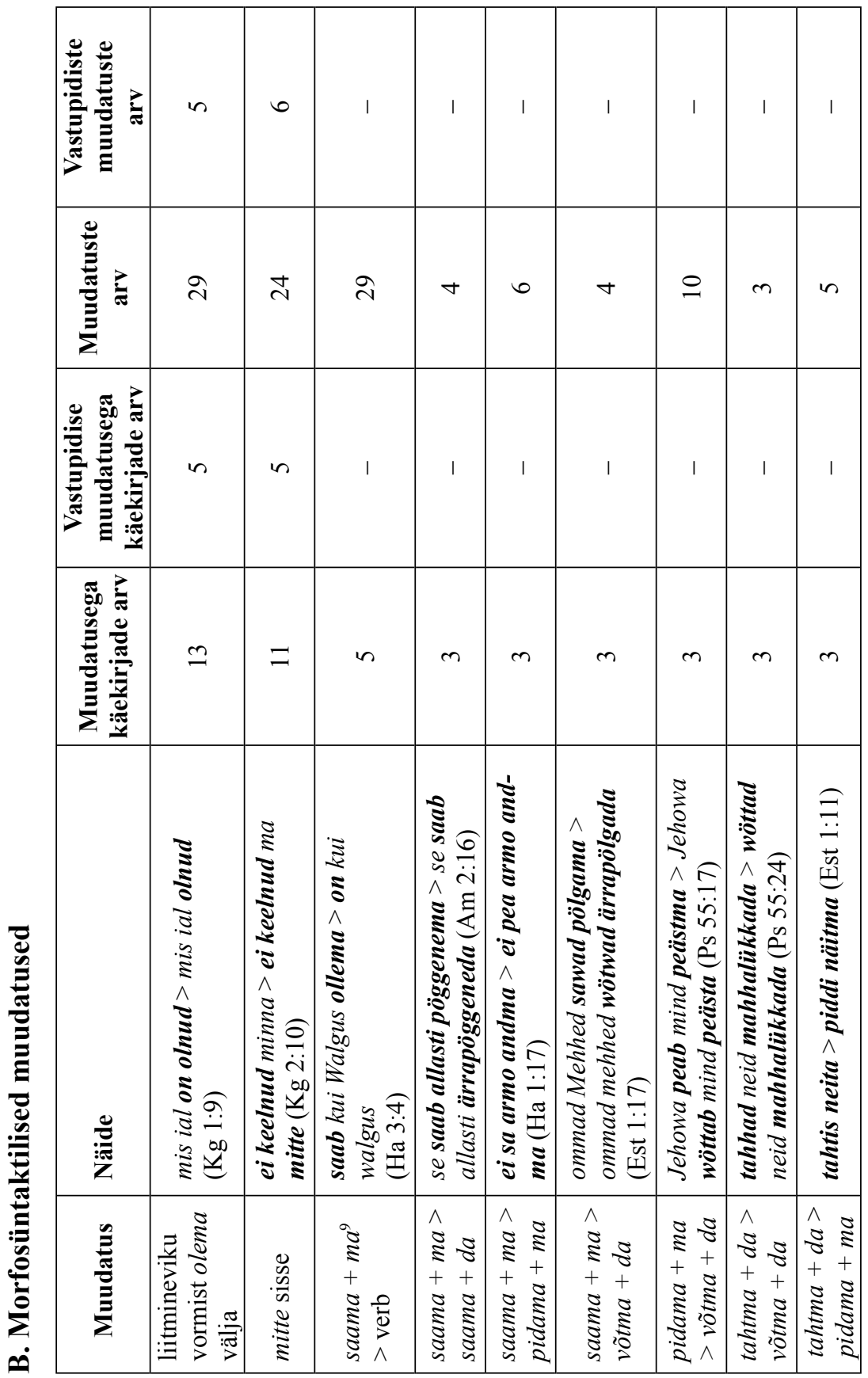




\begin{tabular}{|c|c|c|c|c|c|c|c|c|c|}
\hline 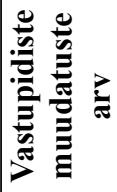 & $\stackrel{0}{ }$ & in & $\nabla$ & 1 & $N$ & $\stackrel{m}{2}$ & 1 & $m$ & $r$ \\
\hline 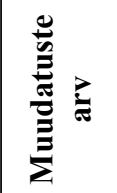 & $r$ & 6 & $\nabla$ & 6 & $a$ & $\stackrel{\sim}{\sim}$ & $\nabla$ & in & $\underline{\theta}$ \\
\hline 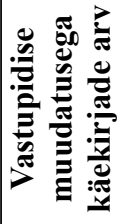 & $\nabla$ & $\nabla$ & $m$ & I & - & $a$ & 1 & $m$ & $r$ \\
\hline 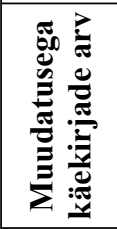 & $n$ & $\nabla$ & $m$ & $n$ & in & 으 & $m$ & in & $\infty$ \\
\hline 党 & 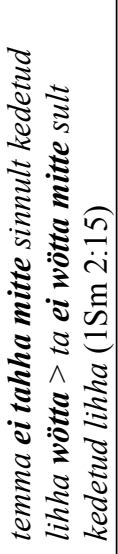 & 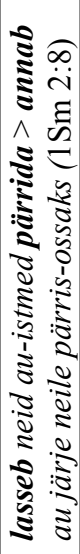 & 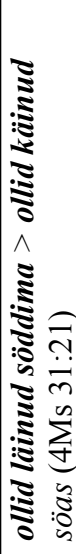 & 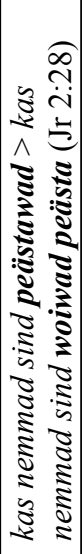 & 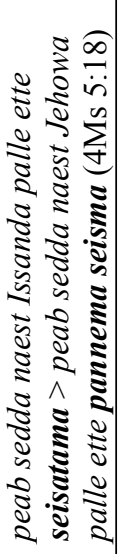 & 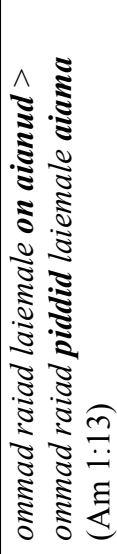 & 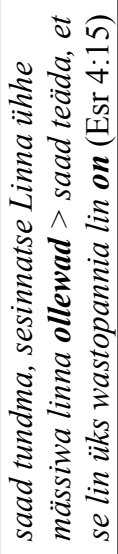 & 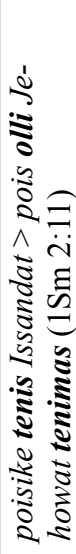 & 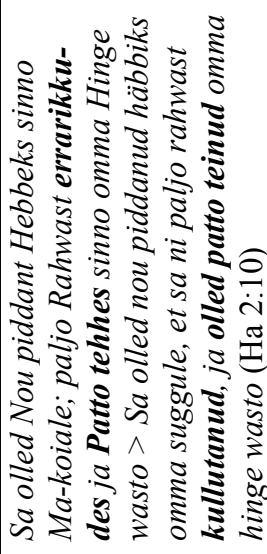 \\
\hline$\underbrace{\stackrel{n}{E}}_{\sum}$ & 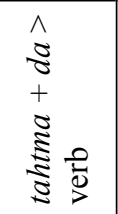 & 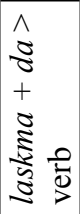 & 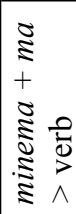 & 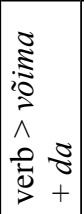 & 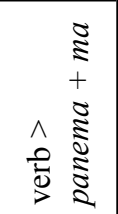 & 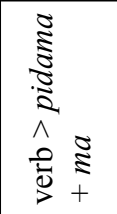 & 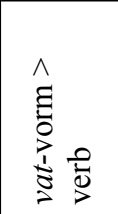 & 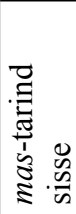 & 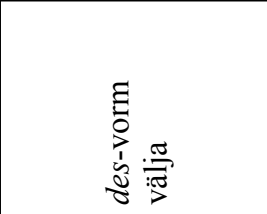 \\
\hline
\end{tabular}




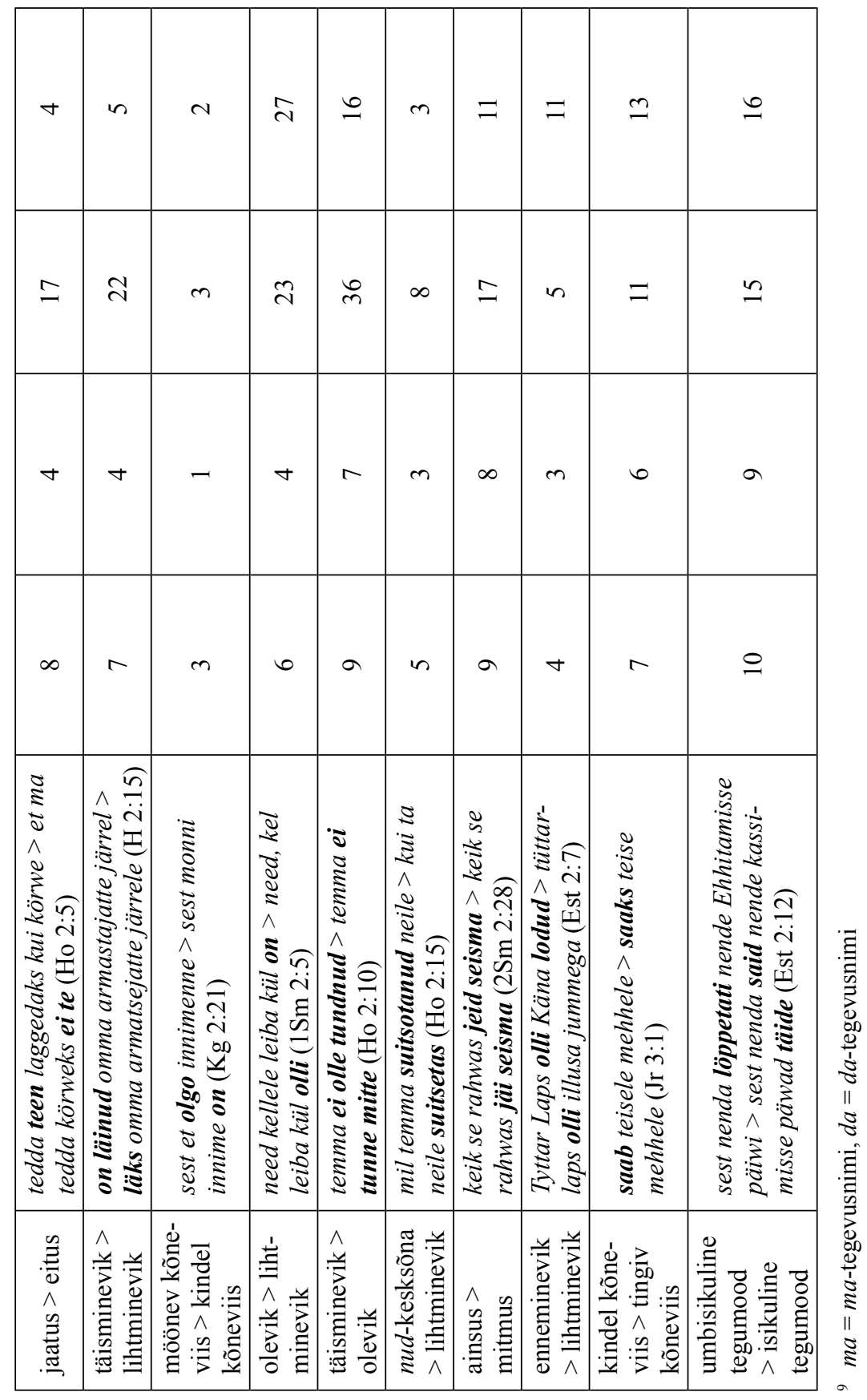




\title{
The handwriting of the editor: how did Anton Thor Helle edit the verb morphology of the Old Testament
}

\author{
Annika Kilgi
}

This article observes the editing process of the first Estonian Bible. The manuscript of the Old Testament was written by several people, but the corrections were made mainly by Anton Thor Helle. In this article, excerpts from 14 handwritings occurring in the canonical books of the Old Testament are observed. The focus is on the places where the editor altered the verb morphology.

It appears that A. Thor Helle corrected the morphology of the predicates and infinitival adverbials often, in about a third of the occurrences. Most of those corrections were minor changes in the wording or different interpretations of the source text, which did not reflect a differing view of the grammatical system. Anton Thor Helle made corrections based on principles frequently only in the texts written by J. N. Wilcken, H. C. Wrede and the unidentified writer of the Book of Ruth. In general, the translators seem to have worked carefully and harmoniously, so that principial corrections were rarely necessary.

For example, there was almost no variation in the usage of $d a$ - and $m a$-infinitive in constructions. The few cases that differed from the generally established pattern were edited by Thor Helle. The consensus was not equally strong in terms of the saama-future, which was used by seven of the fourteen writers and always removed by the editor. His favourite construction was 'võtma $+d a$-infinitive', which he added in many places.

Keywords: history of literary Estonian, Bible translation, morphosyntax, editing

\author{
Annika Kilgi \\ eesti keele ja kultuuri instituut \\ Tallinna Ülikool \\ Narva mnt 25 \\ 10120 Tallinn \\ annika.kilgi@tlu.ee
}

